\section{A) Check for updates}

Cite this: Polym. Chem., 2021, 12, 1086

Received 30th October 2020, Accepted 23rd December 2020 DOI: 10.1039/d0py01519a rsc.li/polymers

\title{
Make or break: Mg(॥)- and Zn(॥)-catalen complexes for PLA production and recycling of commodity polyesters $\dagger$
}

\author{
Jack Payne, ${ }^{a}$ Paul McKeown, (D) ${ }^{\text {b }}$ Oliver Driscoll, ${ }^{\mathrm{b}}$ Gabriele Kociok-Köhn, (DD ${ }^{\mathrm{b}}$ \\ Emma A. C. Emanuelsson ${ }^{c}$ and Matthew D. Jones (iD *a,b
}

\begin{abstract}
Recently we reported a series of highly active Al(III)-complexes bearing a catalen ligand support for lactide polymerisation, observing unprecedented activity in the melt. Herein we report diversification of the metal to furnish a series of well-defined dimeric $\mathrm{Zn}(॥)$ - and $\mathrm{Mg}($ (I)-complexes, which were fully characterised by $X$-ray crystallography and NMR spectroscopy. The production of biocompatible atactic PLA from rac-LA in solution and under industrially preferred solvent-free conditions was demonstrated, typically observing good activity and $M_{n}$ control with a broad range of dispersities $(\theta=1.08-2.04)$. $M g(॥)$-Complexes were shown to facilitate the relatively mild methanolysis of PLA, achieving up to $64 \%$ conversion to Me-LA within $8 \mathrm{~h}$ at $80{ }^{\circ} \mathrm{C}$ in THF. Further kinetic analysis found $[\mathrm{Mg}(\mathbf{1}, \mathbf{3})]_{2}$ to have $k_{\text {app }}$ values of $0.628 \pm 0.0536$ $\{4$ wt $\%$ cat. loading $\}$ and $0.265 \pm 0.0193 \mathrm{~h}^{-1}\{8 \mathrm{wt} \%$ cat. loading $\}$ respectively for the rate of consumption of PLA. Preliminary work extended polymer scope to PET from various sources, demonstrating catalyst versatility
\end{abstract}

\section{Introduction}

Inexpensive, lightweight and robust, plastics remain a tremendous source of social and economic value, providing 1.6 million jobs and turning over $€ 360$ billion in 2018 in Europe alone. ${ }^{1,2}$ However, the current plastics economy remains fundamentally limited, dominated by petroleumbased products operating within a linear model, which underpins mounting environmental concerns. ${ }^{3-8}$ Ocean plastics typify the severity of current plastic pollution with the Great Pacific Garbage Patch (GPGB), an accumulation zone of ocean plastics, encompassing $c a$. 1.6 million $\mathrm{km}^{2}$, equivalent to three times the area of France. ${ }^{9}$ This has stimulated considerable research into renewable and environmentally friendly alternatives, for example poly(lactic acid) (PLA). Traditionally produced from the metal-mediated ring-opening polymerisation (ROP) of lactide (LA), a bio-based monomer feedstock, PLA has

\footnotetext{
${ }^{a}$ Centre for Sustainable and Circular Technologies, University of Bath, Claverton Down, Bath, BA2 7AY, UK

${ }^{b}$ Department of Chemistry, University of Bath, Claverton Down, Bath, BA2 7AY, UK. E-mail:mj205@bath.ac.uk

${ }^{c}$ Department of Chemical Engineering, University of Bath, Claverton Down, Bath, BA2 $7 A Y, U K$

$\dagger$ Electronic supplementary information (ESI) available: Full details of the experimental protocols with selected spectra and raw data. CCDC 2041361-2041367. For ESI and crystallographic data in CIF or other electronic format see DOI: 10.1039/d0py01519a
}

subsequently found commercial use in both the packaging and biomedical sector. ${ }^{3,10-14}$ Recent research has primarily sought to address toxicity concerns associated with the industry standard, $\mathrm{Sn}(\mathrm{Oct})_{2}$, through the development of biocompatible and environmentally benign alternatives. ${ }^{15-17}$ Consequently, a diverse range of metals have been explored, including $\mathrm{Al}(\mathrm{III})^{18-35}$ and group(Iv), ${ }^{36-49}$ with a particular focus on retaining activity whilst maintaining stereocontrol. Metals most pertinent to this report include $\mathrm{Zn}$ (II) and $\mathrm{Mg}$ (II), which are cheap and non-toxic. Zinc complexes have previously been shown to be highly effective initiators for the ROP of LA, generally observing high activity in solution. ${ }^{50-64}$ Pioneering work by Coates and co-workers reported a highly heteroselective $\mathrm{Zn}$ (II)-complex bearing a $\beta$-diiminate ligand, achieving up to $P_{\mathrm{r}}$ $=0.94$ in the ROP of rac-LA at $0{ }^{\circ} \mathrm{C} .{ }^{65}$ Dizinc catalysts supported by macrocyclic ligands developed by Williams and co-workers remain the fastest reported to date under solution conditions, exhibiting high TOFs (up to $60000 \mathrm{~h}^{-1}$ ) at room temperature in THF. ${ }^{66}$ The most isoselective $\mathrm{Zn}$ (II)-complex known is an aminophenolate initiator reported by $\mathrm{Ma}$ and co-workers, which achieved $P_{\mathrm{r}}=0.07$ at $-40{ }^{\circ} \mathrm{C} .{ }^{67}$ McKeown et al. ${ }^{68}$ have reported a series of simple $\mathrm{Zn}$ (II)-Schiff Base complexes capable of achieving TOFs in excess of $100000 \mathrm{~h}^{-1}$ under immortal conditions in the melt. Recently, Hermann et al. ${ }^{69}$ reported a highly active and robust zinc-guanidine complex capable of producing colourless, high molecular weight $\left(M_{\mathrm{n}} \sim 150000 \mathrm{~g} \mathrm{~mol}^{-1}\right)$ PLA within minutes under solvent-free 
conditions $\left(k_{\mathrm{p}}=1.43 \pm 0.09 \mathrm{~L} \mathrm{~mol}^{-1} \mathrm{~s}^{-1}\right)$, culminating in the fastest reported system to date, significantly outperforming $\mathrm{Sn}$ $(\mathrm{Oct})_{2}$. Magnesium complexes have also received significant interest in the ROP of LA. ${ }^{70-82}$ Chisholm and co-workers have reported numerous $\mathrm{Mg}$ (II)-complexes for the production of heterotactic PLA $\left(P_{\mathrm{r}}=0.90-0.96\right) .{ }^{51,83-85}$ Both Coates et al. ${ }^{50}$ (Zn(II), $P_{\mathrm{r}}=0.94 ; \mathrm{Mg}(\mathrm{II})$, atactic PLA) and $\mathrm{Ma}$ et $a .^{58}$ (Zn(II), $\left.P_{\mathrm{r}}=0.20 ; \mathrm{Mg}(\mathrm{II}), P_{\mathrm{r}}=0.81\right)$ have previously shown metal exchange to dramatically impact stereocontrol. Despite such promising advancements, the widespread use of PLA remains limited by a high production cost. ${ }^{3,11}$ Additionally, if not disposed of appropriately, PLA is a potential contributor to the plastic waste crisis. ${ }^{3,86}$ Plastic pollution mitigation requires the industry adopts a circular model, one concerned with material recapture and reuse, with recycling a potential solution. ${ }^{1,3,7}$ Whilst mechanical recycling is traditionally employed, its longterm suitability is limited by eventual material downcycling. ${ }^{2,87}$ A possible alternative is chemical recycling, which enables value-added products such as lactate esters, lactic acid and acrylic acid to be accessed. ${ }^{3,88,89}$ Lactic acid has been identified as a platform chemical, whilst lactate esters have been cited as potential green solvent replacements owing to their low toxicity and biodegradability. ${ }^{90-93}$ It is anticipated the potential for enhanced socio-economic performance will drive market penetration and reduce PLA production costs. ${ }^{94}$ Indeed, the ethyl lactate market is projected to reach \$ 92 million by 2024 and currently trades at $£ 2.54-3.49$ per $\mathrm{kg}$ relative to $£ 1.69$ per $\mathrm{kg}$ for virgin PLA. ${ }^{91,95}$ PLA recycling processes include hydrolysis ${ }^{96-103}$ and alcoholysis. ${ }^{104-115}$ Hydrogenation ${ }^{116-118}$ and hydrosilylation ${ }^{119}$ processes exploiting ruthenium and iridium have also been reported. Simple, commercially available metal salts and precursors (e.g. $\mathrm{FeCl}_{3}$ ) have been shown to facilitate the transesterification of PLA, typically in the presence of methanol to afford methyl lactate (Me-LA). ${ }^{120-122}$ Sobota and co-workers demonstrated the transesterification of PLA using a wide range of alcohols in the presence of $\mathrm{Mg}$ (II) and $\mathrm{Ca}$ (II) pre-catalysts, typically operating under high temperature and pressure regimes. ${ }^{111}$ Organocatalysts have also been exploited in PLA degradation, for example triazabicyclodecene (TBD), 4-(dimethylamino)pyridine (DMAP) and tetramethylammonium methyl carbonate. ${ }^{112-114}$ McKeown et $a .^{123}$ recently demonstrated a homoleptic Zn(II)-complex bearing a propylenediamine backbone to be highly active for PLA methanolysis, achieving $84 \%$ conversion to Me-LA ( $\left.Y_{\text {Me-LA }}\right)$ within $1 \mathrm{~h}$ at $50{ }^{\circ} \mathrm{C}$. The corresponding ethylenediamine analogue exhibited significantly reduced activity $\left(Y_{\mathrm{Me}-\mathrm{LA}}=12 \%\right.$ in $6 \mathrm{~h})$ under comparable conditions $\left(40^{\circ} \mathrm{C}\right)$, highlighting the importance of structure-activity relationships. ${ }^{109,123}$ However, the use of metal-based catalysts for this purpose remains rare despite the plethora reported for LA polymerisation. There is also a clear appetite to diversify metal scope to address potential long-term availability concerns associated with zinc. ${ }^{124}$

We recently reported a series of highly active $\mathrm{Al}(\mathrm{III})-\mathrm{com}$ plexes supported by a catalen framework for lactide polymerisation, observing unprecedented activity in the melt. ${ }^{35}$ However, these complexes are inactive for PLA methanolysis.
Herein, we report diversification of the metal to $\mathrm{Zn}$ (II) and $\mathrm{Mg}$ (II) in pursuit of catalysts active for PLA degradation, for which there is existing literature precedent. ${ }^{109,111,123}$ Consequently, a range of well-defined dimeric $\mathrm{Zn}$ (II)- and $\mathrm{Mg}$ (II)-catalen complexes were prepared, employing a new and emerging class of ligands in the area. Their application to the ROP of rac-LA in solution, and under industrially preferred melt conditions, is discussed. The relatively mild metalmediated methanolysis of PLA into Me-LA is reported. Preliminary work diversifying polyester scope is also demonstrated.

\section{Results and discussion}

\section{Synthesis}

The catalen ligands were prepared via a simple two-step synthesis (Scheme 1), exploiting successive condensation reactions, and characterised by ${ }^{1} \mathrm{H}$ NMR spectroscopy and mass spectrometry (MS). ${ }^{1} \mathrm{H}$ NMR spectroscopic analysis revealed a characteristic singlet at $c a . \delta=8.40 \mathrm{ppm}$, corresponding to a $\mathrm{HC}=\mathrm{N}$ resonance, confirming formation of the imine. The $-\mathrm{CH}_{2}$ resonances were observed as two distinct triplets between $c a . \delta=$ 3.40 and $3.80 \mathrm{ppm}$. Dimeric complexes of $\mathrm{Zn}$ (II) and $\mathrm{Mg}$ (II) were then prepared in anhydrous toluene and recrystallised from the reaction solvent (Scheme 1). All complexes were characterised by single crystal X-ray diffraction (XRD) as shown in Fig. 1. Selected bond lengths and angles for $[\mathrm{Zn}(\mathbf{1}-\mathbf{3})]_{2}$ and $[\mathrm{Mg}(\mathbf{1}-\mathbf{3})]_{2}$ are provided in the ESI. $\dagger \mathrm{A} \mathrm{Zn}(1)-\mathrm{N}(2)$ and $\mathrm{Mg}(1)-\mathrm{N}(2)$ bond length of $c a .2 \AA$ confirmed retention of the imine functionality present in $\mathbf{1}-\mathbf{3} \mathrm{H}_{2}$ upon coordination to the metal centre. In all instances, $\tau_{5}$ values tended towards 1 , indicative of a distorted trigonal bipyramidal geometry (see ESI $\dagger$ ). Interestingly, a highly unusual tetrameric $\mathrm{Mg}$ (II)-complex based on an amine-deprotonated derivative of $2 \mathrm{H}_{2}$ was isolated and characterised by XRD (Fig. 2). Direct concentration of the same solution led to the isolation of $[\mathrm{Mg}(2)]_{2}$ in good purity. The tetramer exhibited an $\mathrm{Mg}$ (1) $-\mathrm{N}(1)$ bond length of ca. $0.20 \AA$ shorter relative to $[\mathrm{Mg}(2)]_{2}$ as expected $\left\{\mathrm{Mg}(1)-\mathrm{N}(1)\right.$ : tetramer, $2.078(4)$; $\left.[\mathrm{Mg}(2)]_{2}, 2.2181(19)\right\}$. Tetrameric analogues based on $1,3 \mathrm{H}_{2}$ and $\mathrm{Zn}$ (II) were not

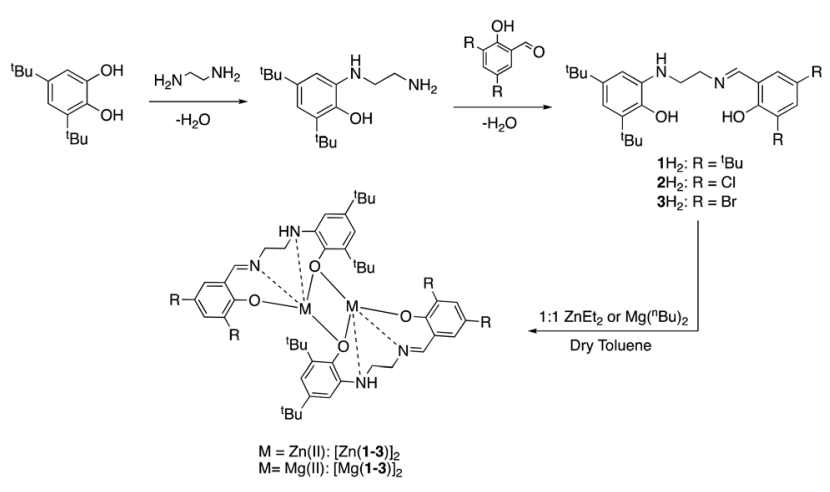

Scheme 1 Catalen ligand preparation and subsequently derived Zn(II)and $\mathrm{Mg}(\mathrm{II})$-complexes. 

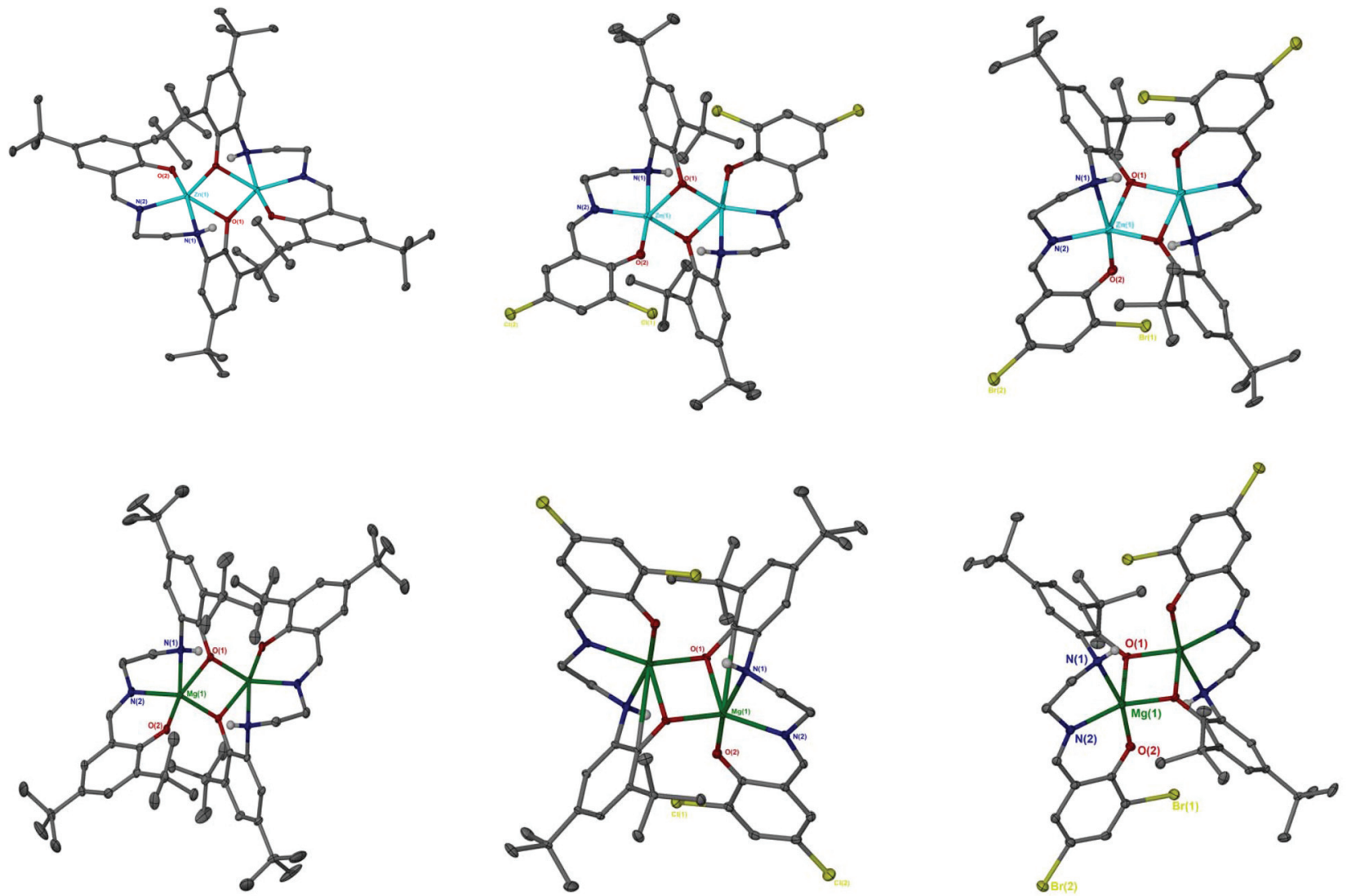

Fig. 1 Solid-state structures of $[\mathrm{Zn}(1-3)]_{2}$ (top left to right) and $[\mathrm{Mg}(1-3)]_{2}$ (bottom left to right). Ellipsoids shown at 30\% probability with the exception of $[\mathrm{Mg}(2)]_{2}$, which is shown at $50 \%$ probability. All hydrogen atoms except those bound to nitrogen or involved in hydrogen bonding, as noted for $[\mathrm{Mg}(2-3)]_{2}$, have been omitted for clarity.

observed, whilst synthesis reattempts were unsuccessful. ${ }^{1} \mathrm{H}$ NMR spectroscopic analysis of $[\operatorname{Zn}(1-3)]_{2}$ and $[\mathrm{Mg}(1-3)]_{2}$ revealed characteristic singlets at $c a . \delta=8.00$ and $4.50 \mathrm{ppm}$

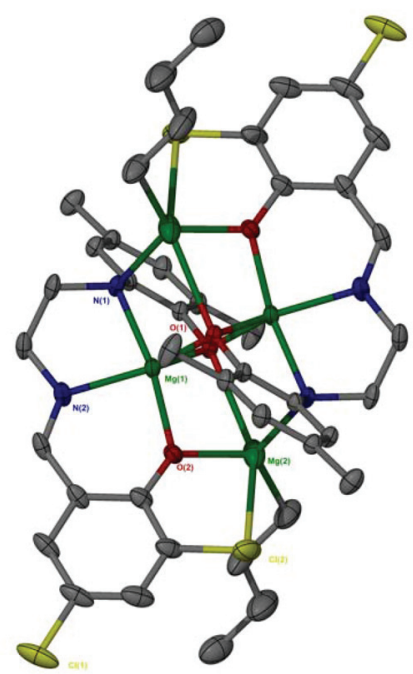

Fig. 2 Solid-state structure of a tetrameric $\mathrm{Mg}(\mathrm{II})$-complex based on an amine-deprotonated derivative of $2 \mathrm{H}_{2}$. Ellipsoids shown at $30 \%$ probability. All hydrogen atoms and methyl groups of the ${ }^{t} \mathrm{Bu}$ groups have been omitted for clarity. corresponding to ArCHN and - $\mathrm{NH}$ resonances respectively. More interestingly, diasterotopic $-\mathrm{CH}_{2}$ resonances between $c a$. $\delta$ $=3.50$ and $4.00 \mathrm{ppm}$ were observed, indicating the ligand is locked in position once coordinated (see ESI $\dagger$ ). ${ }^{13} \mathrm{C}_{\{}\left\{\mathrm{H}^{1}\right\} \mathrm{NMR}$ spectroscopic analysis was consistent with ${ }^{1} \mathrm{H}$ NMR and XRD analysis. It is proposed the dimeric structure observed in the solid-state is retained in solution. $\mathrm{Zn}$ (II)- and $\mathrm{Mg}$ (II)-complexes were in generally good agreement with elemental analysis (EA) data obtained, demonstrating their purity. However, $\mathrm{C} \%$ values were consistently low on $[\mathrm{Mg}(2-3)]_{2}$, potentially due to air and moisture sensitivity confounded by high hygroscopicity, consistent with the $\mathrm{Al}(\mathrm{III})$-catalens. ${ }^{35}$

\section{Polymerisation of rac-LA}

All $\mathrm{Zn}$ (II)- and $\mathrm{Mg}$ (II)-complexes were trialled in the ROP of rac-LA under solvent-free conditions $\left(130\right.$ and $\left.180^{\circ} \mathrm{C}\right)$ in alignment with industrial practices (Table 1). Industrially, solvents are a significant source of waste and thus catalysts that operate under melt conditions are highly desirable. ${ }^{3,15,68,69}$ All initiators were also tested out under solution conditions $\left(80^{\circ} \mathrm{C}\right)$ (Table 2). The lactide monomer, rac-LA, was recrystallised from anhydrous toluene once prior to use and benzyl alcohol $(\mathrm{BnOH})$ was employed as a co-initiator. Conversion was determined via analysis of the methine region ( $c a . \delta=$ 4.9-5.2 ppm) using ${ }^{1} \mathrm{H}$ NMR spectroscopy. To ensure one 
Table 1 Melt polymerisation of rac-LA using $[\mathrm{Zn}(1-3)]_{2}$ and $[\mathrm{Mg}(1,3)]_{2}$

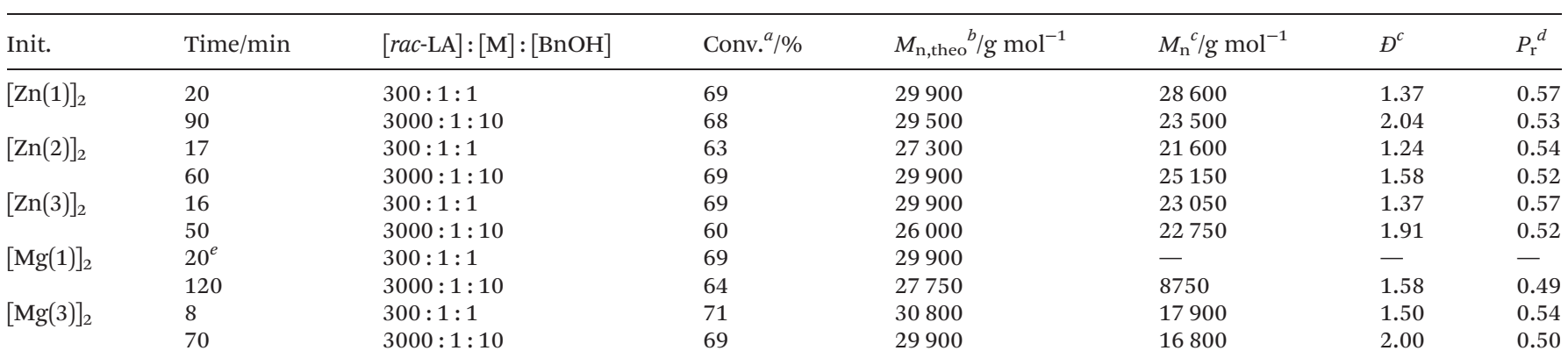

Reaction conditions: rac-LA $(1.0 \mathrm{~g})$, solvent-free $\left(130^{\circ} \mathrm{C}\right) .{ }^{a}$ Determined via ${ }^{1} \mathrm{H}$ NMR spectroscopy. ${ }^{b}$ Theoretical average number molecular weight $\left(M_{\mathrm{n}}\right)$ dependent on conversion and co-initiator added $\left\{\left(M_{\mathrm{r}, \mathrm{LA}} \times 3 \times \%_{\text {conv }}\right)+M_{\mathrm{n}, \mathrm{BnOH}}\right\} .{ }^{c}$ Determined via GPC analysis (in THF). ${ }^{d}$ Determined via homonuclear decoupled NMR spectroscopy. ${ }^{e}$ Insufficient polymeric material isolated for material characterisation. N.B. $\{[\mathrm{rac}-\mathrm{LA}]:[\mathrm{M}]:[\mathrm{BnOH}]=$ $3000: 1: 10\}$ were performed at $180^{\circ} \mathrm{C} .[\mathrm{M}]:[\mathrm{BnOH}]=1: 1$ corresponds to 1 equivalent of $\mathrm{BnOH}$ per metal centre. Monomer conversion plateau between $60-70 \%$ can be attributed to reduced catalyst activity coupled with mass transfer limitations.

Table 2 Solution polymerisation of rac-LA using $[\mathrm{Zn}(1-3)]_{2}$ and $[\mathrm{Mg}(1,3)]_{2}$

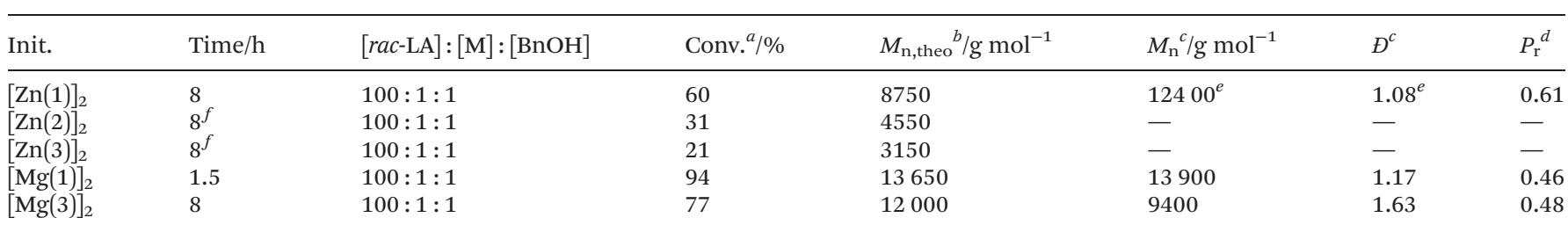

Reaction conditions: rac-LA $(0.5 \mathrm{~g})$, solvent (toluene, $\left.80{ }^{\circ} \mathrm{C}\right) .{ }^{a}$ Determined via ${ }^{1} \mathrm{H}$ NMR spectroscopy. ${ }^{b}$ Theoretical average number molecular weight $\left(M_{\mathrm{n}}\right)$ dependent on conversion and co-initiator added $\left\{\left(M_{\mathrm{r}, \mathrm{LA}} \times \%_{\text {conv }}\right)+M_{\mathrm{n}}, \mathrm{BnOH}\right\} .{ }^{c}$ Determined via GPC analysis (in THF). ${ }^{d}$ Determined via homonuclear decoupled NMR spectroscopy. ${ }^{e}$ Bimodal GPC observed, distributions treated together for reported $M_{\mathrm{n}}$ and $D$ values. ${ }^{f}$ Insufficient polymeric material isolated for material characterisation. N.B. $[\mathrm{M}]:[\mathrm{BnOH}]=1: 1$ corresponds to 1 equivalent of $\mathrm{BnOH}$ per metal centre.

-OBn moiety was associated per metal centre, both $\mathrm{Zn}$ (II)- and $\mathrm{Mg}$ (II)-complexes were treated as monomeric. It is proposed $[\mathrm{Zn}(\mathbf{1}-\mathbf{3})]_{2}$ and $[\mathrm{Mg}(\mathbf{1}-\mathbf{3})]_{2}$ operate via an activated-monomer mechanism. To investigate this the stability of $[\operatorname{Zn}(\mathbf{1})]_{2}$ with excess $\mathrm{BnOH}$ was studied using ${ }^{1} \mathrm{H}$ NMR $\left(\mathrm{CDCl}_{3}\right)$, which confirmed $[\mathrm{Zn}(\mathbf{1})]_{2}$ to be stable at both room temperature and $80{ }^{\circ} \mathrm{C}$ (see ESI†). Due to a poor isolation yield $(0.065 \mathrm{~g}, 14 \%)$, $[\mathrm{Mg}(2)]_{2}$ was not pursued in polymerisation studies but was expected to exhibit comparable activity to $[\mathrm{Mg}(3)]_{2}$ based on previous work. $^{35}$

All Zn(II)-complexes exhibited good activity at $130{ }^{\circ} \mathrm{C}$, achieving reasonably high conversion within 20 minutes $\{[$ rac-LA $]:[\mathrm{M}]:[\mathrm{BnOH}]=300: 1: 1\}$ (Table 1). $[\mathrm{Zn}(2-3)]_{2}$ exhibited superior activity relative to $[\mathrm{Zn}(\mathbf{1})]_{2}$, presumably owing to a more Lewis acid $\mathrm{Zn}$ (II)-centre. $[\mathrm{Zn}(\mathbf{1})]_{2}$ exhibited excellent $M_{\mathrm{n}}$ control $\left(M_{\mathrm{n}, \text { theo }}=29900 \mathrm{~g} \mathrm{~mol}{ }^{-1}, M_{\mathrm{n}}=28600 \mathrm{~g} \mathrm{~mol}^{-1}\right.$; Table 1, entry 1), whilst reasonable $M_{\mathrm{n}}$ control was maintained for $[\operatorname{Zn}(2-3)]_{2}$, observing moderate dispersities $(D=1.24-1.37)$ in all cases. Reducing the catalyst loading to $0.033 \mathrm{~mol} \%$ at $180^{\circ} \mathrm{C}$ to simulate industrial conditions resulted in prolonged polymerisation times, achieving between $60-69 \%$ within 50 to 90 minutes $\{[r a c-\mathrm{LA}]:[\mathrm{M}]:[\mathrm{BnOH}]=3000: 1: 10\}$ (Table 1 ). The reactivity trend noted for $[\mathrm{Zn}(1-3)]_{2}$ was exacerbated under these conditions, likely due to an increase in temperature assisting catalyst dissociation and solubility. Interestingly, $[\mathrm{Zn}(1)]_{2}$ exhibited poorer $M_{\mathrm{n}}$ control $\left(M_{\mathrm{n}, \text { theo }}=29500 \mathrm{~g} \mathrm{~mol}^{-1}\right.$, $M_{\mathrm{n}}=23500 \mathrm{~g} \mathrm{~mol}^{-1}$; Table 1, entry 2;), whilst comparable control was retained for $[\mathrm{Zn}(2-3)]_{2}$ under these conditions. Generally, a lower $M_{\mathrm{n}}$ value than expected (relative to theoretical values) was observed, possibly indicative of side transesterification reactions, consistent with the broader dispersities observed $(\theta=1.58-2.04)$. Reactivity trends discussed for $[\mathrm{Zn}(1-3)]_{2}$ could be extended to the $\mathrm{Mg}(\mathrm{II})$-catalen series, observing comparable activity between $[\operatorname{Zn}(\mathbf{1})]_{2}$ and $[\mathrm{Mg}(\mathbf{1})]_{2}$ at $130{ }^{\circ} \mathrm{C}$ (Table 1). Both $[\mathrm{Mg}(\mathbf{1}, \mathbf{3})]_{2}$ exhibited reduced activity relative to their $\mathrm{Zn}$ (II) counterparts at $180{ }^{\circ} \mathrm{C}$, suggesting the active species to be inherently less active, despite $[\mathrm{Mg}(3)]_{2}$ $\left(71 \%\right.$, 8 min; Table 1, entry 9;) outperforming $[\operatorname{Zn}(3)]_{2}(69 \%$, $16 \mathrm{~min}$; Table 1 , entry 5;) at $130{ }^{\circ} \mathrm{C}$. However, significantly lower $M_{\mathrm{n}}$ values relative to those reported for the $\mathrm{Al}(\mathrm{III})$-catalens $\left(M_{\mathrm{n}}=160500-252100 \mathrm{~g} \mathrm{~mol}^{-1}\right)$ were observed, implying $k_{\mathrm{p}}$ to be significantly slower relative to $k_{\mathrm{i}}$, possibly due to a mechanism shift. Under both sets of conditions, $[\mathrm{Mg}(\mathbf{1}, \mathbf{3})]_{2}$ exhibited poor $M_{\mathrm{n}}$ control $\left(M_{\mathrm{n}, \text { theo }}=27750-30800 \mathrm{~g} \mathrm{~mol}^{-1}, M_{\mathrm{n}}=\right.$ 8750-17900 $\left.\mathrm{g} \mathrm{mol}^{-1}\right)$. MALDI-ToF analysis confirmed the polymer (Table 1, entry 8) to be -OBn and -H end-capped with multiple series present indicating a high degree of transesterification (see ESI $\dagger$ ), consistent with the broad dispersities 
observed $(~ D=1.50-2.00)$. Metal exchange was found to have no impact on stereocontrol, observing the production of atactic PLA in all instances $\left(P_{\mathrm{r}}=0.49-0.57\right)$.

Under solution conditions $\{[r a c-\mathrm{LA}]:[\mathrm{M}]:[\mathrm{BnOH}]=$ $100: 1: 1\}$ (Table 2), $[\mathrm{Zn}(\mathbf{1})]_{2}$ exhibited good polymerisation control, producing PLA of reasonably well-defined $M_{\mathrm{n}}$ $\left(M_{\mathrm{n}, \text { theo }}=8750 \mathrm{~g} \mathrm{~mol}^{-1}, M_{\mathrm{n}}=12400 \mathrm{~g} \mathrm{~mol}^{-1} ;\right.$ Table 2 , entry 1$)$ and narrow dispersities $(\fallingdotseq=1.08)$. GPC analysis revealed the $M_{\mathrm{n}}$ distribution to be bimodal in nature (see ESI $\dagger$ ). Surprisingly, $[\mathrm{Zn}(2-3)]_{2}$ exhibited poorer activity relative to $[\mathrm{Zn}(\mathbf{1})]_{2}$, achieving between $21-31 \%$ conversion within $8 \mathrm{~h}$, contrary to reactivity trends discussed for the melt (Table 1). This activity loss could potentially be due to greater catalyst aggregation under these conditions, which limits availability of the active species. Indeed, kinetically limited dissociation was previously reported for the $\mathrm{Al}$ (III)-catalens, resulting in a loss in polymerisation control. ${ }^{35}$ This trend was reflected in the $\mathrm{Mg}$ (II)-series but appeared less prevalent, consistent with observations in the melt. Promisingly, both $[\operatorname{Mg}(\mathbf{1}, \mathbf{3})]_{2}$ outperformed their $\mathrm{Zn}$ (II) counterpart, achieving $94 \%$ and $77 \%$ conversion within 1.5 and $8 \mathrm{~h}$ respectively. MALDI-ToF analysis confirmed polymer produced by $[\mathrm{Mg}(3)]_{2}$ (Table 2 , entry 5 ) to be $-\mathrm{OBn}$ and $-\mathrm{H}$ end-capped and transesterified, consistent with GPC analysis $\left(M_{\mathrm{n}, \text { theo }}=12000 \mathrm{~g} \mathrm{~mol}^{-1}, M_{\mathrm{n}}=9400 \mathrm{~g}\right.$ $\mathrm{mol}^{-1}, \oplus=1.63$; Table 2, entry 5) (see ESI $\dagger$ ). Interestingly, $[\mathrm{Mg}(\mathbf{1})]_{2}$ also facilitated intermolecular transesterification, consistent with a $72 \mathrm{~g} \mathrm{~mol}^{-1}$ peak separation in the MALDI-ToF spectra (see ESI $\dagger$ ), but maintained excellent polymerisation control $\left(M_{\mathrm{n}, \text { theo }}=13650 \mathrm{~g} \mathrm{~mol}{ }^{-1}, M_{\mathrm{n}}=13900 \mathrm{~g} \mathrm{~mol}^{-1}\right.$, $Ð=1.17$; Table 2, entry 4). It is possible transesterification was exacerbated during polymer work up in the presence of $\mathrm{MeOH}$, consistent with the melt (Table 1 , entries $7-10)$. $[\mathrm{Mg}(\mathbf{1}, \mathbf{3})]_{2}$ produced atactic polymer $\left(P_{\mathrm{r}}=0.46-0.48\right)$, whilst $[\mathrm{Zn}(\mathbf{1})]_{2}$ afforded PLA with a slight heterotactic bias $\left(P_{\mathrm{r}}=0.61\right)$. In summary, all $\mathrm{Zn}$ (II)- and $\mathrm{Mg}$ (II)-complexes exhibited good activity in the production of biocompatible atactic PLA, although non-competitive with the industry standard; $\mathrm{Sn}(\mathrm{Oct})_{2}$.

\section{Polymerisation kinetics}

To ascertain a better understanding of metal-ligand cooperative effects on activity, a kinetic study was pursued using $[\mathrm{Zn}(\mathbf{1})]_{2}$ and $[\mathrm{Mg}(\mathbf{1})]_{2}$ as a model system. A plot of $\ln \left([\mathrm{LA}]_{0} /\right.$ $[\mathrm{LA}]_{t}$ ) against time exhibited a linear relationship, indicating the reaction to be pseudo-first-order with respect to the consumption of rac-LA (Fig. 3). $[\mathrm{Mg}(\mathbf{1})]_{2}$ exhibited an apparent rate constant $\left(k_{\text {app }}\right)$ of $0.0206 \mathrm{~min}^{-1}$, over 12 orders of magnitude higher relative to $[\mathrm{Zn}(\mathbf{1})]_{2}\left(k_{\mathrm{app}}=0.0017 \mathrm{~min}^{-1}\right)$, consistent with solution results (Table 2 ). Indeed, $[\operatorname{Zn}(\mathbf{1})]_{2}$ also exhibited an induction period of $c a$. 40 minutes, potentially evidencing catalyst aggregation under these conditions. No induction period was observed for $[\mathrm{Mg}(\mathbf{1})]_{2}$, highlighting judicial choice of the metal can circumvent such limitations. It is tentatively suggested such aggregation is H-bonding in nature, although metal influence remains poorly understood. GPC analysis of the aliquots retained for $[\mathrm{Mg}(\mathbf{1})]_{2}$ confirmed the polymerisation to be well controlled and living (Fig. 4). This was demon-

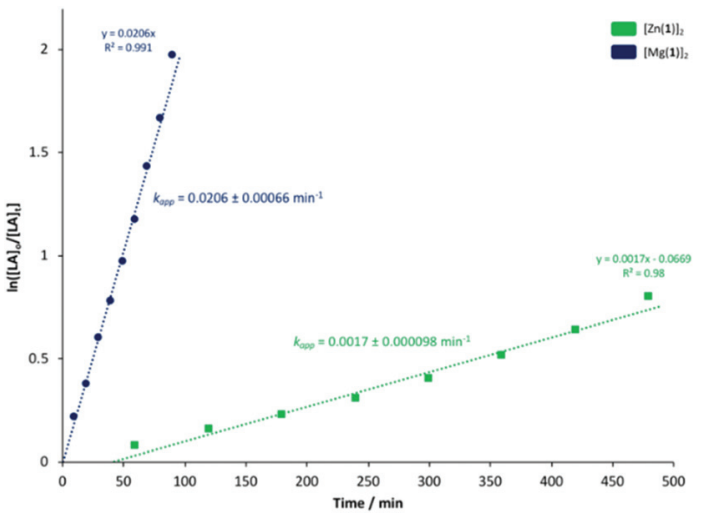

Fig. 3 Pseudo-first-order logarithmic plot for the polymerisation of rac-LA at $80{ }^{\circ} \mathrm{C}$ in toluene $\{[\mathrm{rac}-\mathrm{LA}]:[\mathrm{M}]:[\mathrm{BnOH}]=100: 1: 1\}$ using $[\mathrm{Zn}(1)]_{2}$ and $[\mathrm{Mg}(1)]_{2}$. N.B. $[\mathrm{LA}]_{0}=0.69 \mathrm{~mol} \mathrm{dm}^{-3}$.

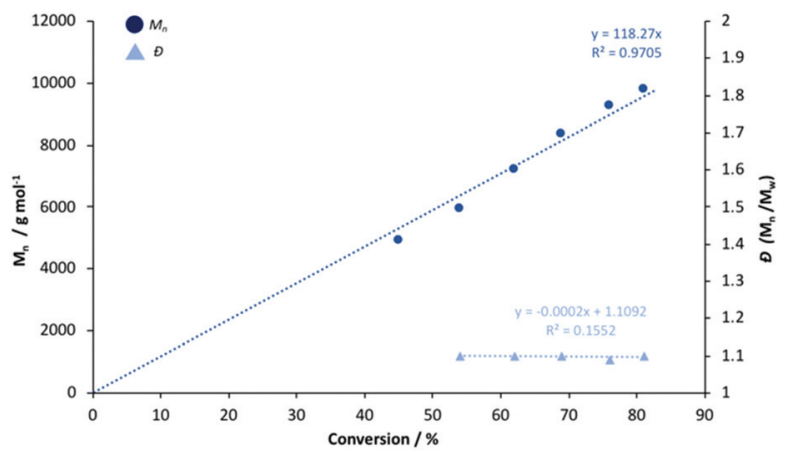

Fig. 4 Linear plot of $M_{n}$ and $\oslash$ against conversion for the polymerisation of rac-LA at $80{ }^{\circ} \mathrm{C}$ in toluene $\{[\mathrm{rac}-\mathrm{LA}]:[\mathrm{M}]:[\mathrm{BnOH}]=100: 1: 1\}$ using $[\mathrm{Mg}(1)]_{2}$.

strated by a linear increase in $M_{\mathrm{n}}$ with conversion whilst maintaining narrow dispersities. A slightly lower $M_{\mathrm{r} \text {,monomer relative }}$ to ideal PLA was observed $\left(M_{\mathrm{r}, \text { theo }}=144.12 \mathrm{~g} \mathrm{~mol} \mathrm{~m}^{-1}\right.$, $M_{\mathrm{r}}=118.27 \mathrm{~g} \mathrm{~mol}^{-1}$ ), which could likely be attributed to minor transesterification, consistent with MALDI-ToF analysis (see $\mathrm{ESI} \dagger$ ).

\section{Polyester recycling}

PLA degradation. $[\mathrm{Zn}(\mathbf{1}-\mathbf{3})]_{2}$ and $[\mathrm{Mg}(\mathbf{1}, \mathbf{3})]_{2}$ were investigated in the metal-mediated degradation of PLA into Me-LA in solution at $80^{\circ} \mathrm{C}$ (Fig. 5 and Table 3). Whilst Me-LA is a possible green solvent replacement, it is also a potentially valuable chemical to the PLA supply chain since it can be directly converted to lactide. ${ }^{3,91}$ Commercially available polymer $(0.25 \mathrm{~g}$, PLLA cup, $M_{\mathrm{n}}=45510 \mathrm{~g} \mathrm{~mol}^{-1}$ ) and catalyst were dissolved in either THF or anhydrous toluene under Ar, with heat and stirring assisting dissolution. $\mathrm{MeOH}$ was then added and the conversion to Me-LA was determined via ${ }^{1} \mathrm{H}$ NMR analysis of the methine region ( $c a . \delta=4.2-5.2 \mathrm{ppm}$ ). The production of Me-LA has previously been shown to proceed via a two-step process through the intermediate formation of chain-end groups (see ESI $\dagger)^{109,123}$ 

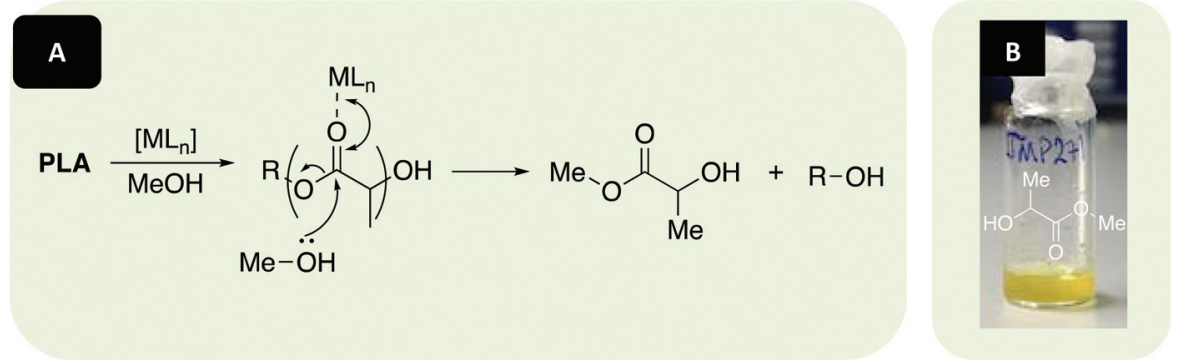

Fig. 5 (A) Metal-mediated degradation mechanism of PLA into methyl lactate (Me-LA) via transesterification with MeOH, where R denotes the growth polymer chain. (B) Example of recycled product (Me-LA). N.B. Discolouration in Me-LA product (B, liquid) originates from catalyst used $\left([\mathrm{Mg}(1)]_{2}-\right.$ yellow solid).

Table 3 Degradation of PLA into Me-LA using $[\mathrm{Zn}(1-3)]_{2}$ and $[\mathrm{Mg}(1,3)]_{2}$

\begin{tabular}{|c|c|c|c|c|c|c|c|}
\hline Catalyst & Time/h & $T /{ }^{\circ} \mathrm{C}$ & Cat. loading/wt\% & $Y_{\mathrm{Me}-\mathrm{LA} / \%}$ & $S_{\mathrm{Me}-\mathrm{LA} / \%}$ & $X_{\mathrm{int} / \%}$ & $k_{\text {app }} / \mathrm{h}^{-1}$ \\
\hline & 8 & 80 & 4 & 4 & 9 & 46 & - \\
\hline & $8^{a}$ & 80 & 4 & 7 & 12 & 57 & - \\
\hline \multirow[t]{3}{*}[\mathrm{Zn}(2)]{$_{2}$} & 8 & 80 & 8 & 0 & 0 & 42 & - \\
\hline & 8 & 80 & 4 & 0 & 0 & 20 & - \\
\hline & $8^{a}$ & 80 & 8 & 4 & 9 & 44 & - \\
\hline & $8^{a}$ & 80 & 8 & 0 & 0 & 37 & - \\
\hline \multirow[t]{3}{*}[\mathrm{Mg}(1)]{$_{2}$} & 8 & 80 & 2 & 10 & 36 & 28 & - \\
\hline & 8 & 80 & 4 & 64 & 66 & 97 & 0.628 \\
\hline & 8 & 80 & 8 & 31 & 56 & 55 & 0.0819 \\
\hline \multirow[t]{3}{*}[\mathrm{Mg}(3)]{$_{2}$} & 8 & 80 & 2 & 13 & 38 & 34 & - \\
\hline & 8 & 80 & 4 & 42 & 63 & 67 & - \\
\hline & 8 & 80 & 8 & 64 & 77 & 83 & 0.265 \\
\hline
\end{tabular}

Reaction conditions: $0.25 \mathrm{~g}$ of PLLA cup $\left(M_{\mathrm{n}}=45510 \mathrm{~g} \mathrm{~mol}{ }^{-1}\right), V_{\mathrm{THF}}: V_{\mathrm{MeOH}}=4: 1, n_{\mathrm{MeOH}}: n_{\mathrm{ester}}=7: 1,[\mathrm{Zn}(1-3)]_{2}=4-8$ wt $\%$ cat. loading $\left(0.24-0.58 \mathrm{~mol} \%\right.$ relative to ester linkages), $[\mathrm{Mg}(\mathbf{1}, 3)]_{2}=2-8 \mathrm{wt} \%$ cat. loading $\left(0.13-0.57 \mathrm{~mol} \%\right.$ relative to ester linkages). $Y_{\mathrm{Me}-\mathrm{LA}}, S_{\mathrm{Me}-\mathrm{LA}}$ and $X_{\mathrm{int}}$ determined by ${ }^{1} \mathrm{H}$ NMR upon solvent removal. ${ }^{a}$ Solvent: Anhydrous toluene, $V_{\text {toluene }}: V_{\mathrm{MeOH}}=4: 1$.

Consequently, the methine groups can be categorised as internal (int), chain-end (CE) and those corresponding directly to the alkyl lactate (Me-LA). Conversion of internal methine units $\left(X_{\text {int }}\right)$, methyl lactate selectivity $\left(S_{\text {Me-LA }}\right)$ and Me-LA yield $\left(Y_{\text {Me-LA }}\right)$ are tabulated in Table 3 below. $[\mathrm{Zn}(\mathbf{1})]_{2}$ exhibited reasonably poor activity at $8 \mathrm{wt} \%$, achieving $19 \%$ conversion to Me-LA within $8 \mathrm{~h}$ in THF with poor selectivity (Table 3, entry 1). Promisingly, superior activity and selectivity $\left(Y_{\mathrm{Me}-\mathrm{LA}}=\right.$ $51 \%, S_{\text {Me-LA }}=53 \%$, ) was observed upon shifting to a non-coordinating solvent, namely anhydrous toluene (Table 3 , entry 3 ). This implies THF competes with the degrading polymeric chain with respect to coordination to the $\mathrm{Zn}$ (II)-centre, consistent with the near complete consumption of PLA $\left(X_{\mathrm{int}}=96 \%\right)$. Interestingly, shifting to a more electron withdrawing catalen backbone in $[\mathrm{Zn}(2-3)]_{2}$ had a detrimental impact on $Y_{\mathrm{Me}-\mathrm{LA}}$, achieving 0\% conversion to Me-LA under analogous conditions in THF. Whilst contrary to previous work by Payne et al., ${ }^{110}$ this was consistent with solution polymerisation results (Table 2). Indeed, previously described solution reactivity trends were retained for PLA degradation. Since this behaviour was retained in anhydrous toluene, it is suggested the afore- mentioned activity loss due to possible catalyst aggregation (Table 2) likely persists under these conditions. It is possible bulky ${ }^{t} \mathrm{Bu}$ substituents promote the dissociation of $[\mathrm{Zn}(\mathbf{1})]_{2}$ in solution, resulting in superior activity relative to $[\mathrm{Zn}(2-3)]_{2}$. $[\mathrm{Mg}(\mathbf{1})]_{2}$ significantly outperformed its $\mathrm{Zn}$ (II)-counterpart, achieving $31 \%$ conversion to Me-LA with good selectivity in THF at 8 wt\% (Table 3, entry 13). Interestingly, significantly enhanced activity was realised upon decreasing the catalyst loading to 4 wt $\%\left(Y_{\text {Me-LA }}=64 \%, S_{\text {Me-LA }}=66 \%, X_{\text {int }}=97 \%\right)$, possibly evidencing a reduction in catalyst aggregation due to dilution. To improve industrial feasibility and investigate the limit of this effect, the catalyst loading was further reduced to $2 \mathrm{wt} \%$. Significantly reduced $Y_{\text {Me-LA }}$ relative to $4 \mathrm{wt} \%$ was observed (Table 3, entries 11 and 12), implying unavailability of the active species predominates, consistent with $[\mathrm{Mg}(3)]_{2}$ (Table 3 , entry 14). In light of this, $[\operatorname{Zn}(1-3)]_{2}$ were investigated at $4 \mathrm{wt} \%$ in both $\mathrm{THF}$ and anhydrous toluene at $80{ }^{\circ} \mathrm{C}$, although no activity enhancement was observed. $[\mathrm{Mg}(3)]_{2}$ exhibited superior activity relative to $[\mathrm{Zn}(3)]_{2}$, achieving $42 \%$ conversion to Me-LA within $8 \mathrm{~h}$ at $4 \mathrm{wt} \%$ (Table 3, entry 15). Whilst lower relative to $[\mathrm{Mg}(\mathbf{1})]_{2}$, enhanced $Y_{\text {Me-LA }}$ and $S_{\text {Me-LA }}$ 
was observed at $8 \mathrm{wt} \%$ (Table 3, entry 16). This implies the liberated species to be inherently more active relative to $[\mathrm{Mg}(\mathbf{1})]_{2}$ and that possible catalyst aggregation dominates at $4 \mathrm{wt} \%$. Judicial choice of the metal had previously been shown to circumvent such challenges in the solution polymerisation of rac-LA (Fig. 3). Degradation reactions using $[\mathrm{Mg}(\mathbf{1}, \mathbf{3})]_{2}$ in anhydrous toluene were not pursued in alignment with the 12 principles of green chemistry. ${ }^{125}$ Overall, mass transfer limitations due to polymer particle size and stirring speeds were considered negligible based on previous work by RománRamírez et al., ${ }^{109}$ which employed a homoleptic Zn(II)-complex bearing an ethylenediamine Schiff-base ligand.

PLA degradation kinetics. $[\mathrm{Mg}(\mathbf{1})]_{2}$ and $[\mathrm{Mg}(\mathbf{3})]_{2}$ were identified as the outstanding candidates and thus pursued for further kinetic analysis. Reaction progress was monitored hourly for the first 4 hours for ${ }^{1} \mathrm{H}$ NMR $\left(\mathrm{CDCl}_{3}\right)$ analysis of the methine region. A final aliquot was taken after 8 hours for analysis, totalling 5 data points (Fig. 6). PLA consumption was assumed to adopt pseudo-first-order kinetics in accordance to previous work by Román-Ramírez et al. ${ }^{109}$ Consequently, the gradient of the logarithmic plot is equivalent to the apparent rate constant, $k_{\text {app }}$ (Table 3 and Fig. 6). $[\mathrm{Mg}(\mathbf{1})]_{2}$ exhibited a $k_{\text {app }}$ value of $0.628 \pm 0.0536$ and $0.0819 \pm 0.0213 \mathrm{~h}^{-1}$ at 4 and $8 \mathrm{wt} \%$ respectively in THF, indicating an increase in catalyst loading results in a statistically significant decrease in activity. $[\mathrm{Mg}(3)]_{2}$ was found to have a $k_{\text {app }}$ value of $0.265 \pm 0.0193 \mathrm{~h}^{-1}$, lower relative to $[\mathrm{Mg}(\mathbf{1})]_{2}$, consistent with preliminary methanolysis results (Table 3 ). Comparable $Y_{\text {Me-LA }}$ values (Table 4) were observed relative to Table 3 , indicating good reproducibility. Whilst promising, these $k_{\text {app }}$ value remain lower compared to previously reported $\mathrm{Zn}$ (II)-complexes $\left(k_{\text {app }}=0.44-12.0 \mathrm{~h}^{-1}\right.$ ) operating between 50 to $80{ }^{\circ} \mathrm{C}$ under analogous reaction conditions. ${ }^{109,110,123}$ However, to the best of our knowledge, $[\mathrm{Mg}(\mathbf{1}, \mathbf{3})]_{2}$ represent the first example of PLA methanolysis mediated by a well-defined discrete $\mathrm{Mg}$ (II)-complex, operating under significantly milder conditions relative to Petrus et al. ${ }^{111}$ who relied upon metallic $\mathrm{Mg}$ or $\mathrm{Mg}\left({ }^{n} \mathrm{Bu}\right)_{2}$ as pre-catalysts. For $[\mathrm{Mg}(\mathbf{1}, \mathbf{3})]_{2}$, inspection of the ${ }^{1} \mathrm{H}$ NMR (Table 3,

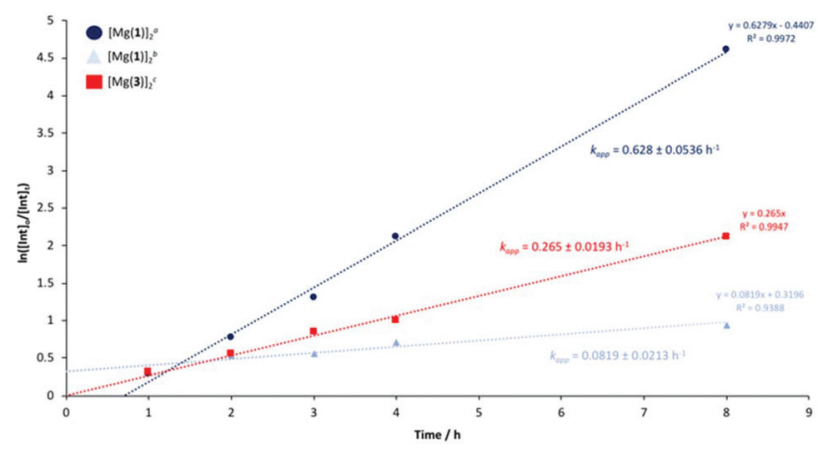

Fig. 6 Pseudo-first-order logarithmic plot for the degradation of PLLA cup using $[\mathrm{Mg}(1)]_{2}$ and $[\mathrm{Mg}(3)]_{2}$ in $\mathrm{THF}$ at $80{ }^{\circ} \mathrm{C} .{ }^{a}[\mathrm{Mg}(1)]_{2}=4 \mathrm{wt} \%$ cat. loading $\left(0.29 \mathrm{~mol} \%\right.$ relative to ester linkages). ${ }^{b}[\mathrm{Mg}(1)]_{2}=8 \mathrm{wt} \%$ cat. loading $\left(0.57 \mathrm{~mol} \%\right.$ relative to ester linkages). ${ }^{c}[\mathrm{Mg}(3)]_{2}=8 \mathrm{wt} \%$ cat. loading ( 0.53 mol\% relative to ester linkages).
Table 4 PLLA cup degradation using $[\mathrm{Mg}(1,3)]_{2}$ in $\mathrm{THF}$ at $80^{\circ} \mathrm{C}$

\begin{tabular}{lll}
\hline Catalyst & $Y_{\text {Me-LA }} / \%$ & $k_{\text {app }} / \mathrm{h}^{-1}$ \\
\hline$[\mathrm{Mg}(\mathbf{1})]_{2}{ }^{a}$ & 76 & $0.628 \pm 0.0536$ \\
{$[\mathrm{Mg}(\mathbf{1})]_{2}{ }^{b}$} & 38 & $0.0819 \pm 0.0213$ \\
{$[\mathrm{Mg}(\mathbf{3})]_{2}{ }^{c}$} & 63 & $0.265 \pm 0.0193$
\end{tabular}

Reaction conditions: $0.25 \mathrm{~g}$ of PLLA cup $\left(M_{\mathrm{n}}=45510 \mathrm{~g} \mathrm{~mol}{ }^{-1}\right)$, $V_{\mathrm{THF}}: V_{\mathrm{MeOH}}=4: 1, n_{\mathrm{MeOH}}: n_{\mathrm{ester}}=7: 1$. Error associated with $k_{\text {app }}$ calculated using linear regression. ${ }^{a}[\mathrm{Mg}(\mathbf{1})]_{2}=4 \mathrm{wt} \%$ cat. loading $\left(0.29 \mathrm{~mol} \%\right.$ relative to ester linkages). ${ }^{b}[\mathrm{Mg}(\mathbf{1})]_{2}=8 \mathrm{wt} \%$ cat. loading (0.57 mol\% relative to ester linkages). ${ }^{c}[\mathrm{Mg}(3)]_{2}=8 \mathrm{wt} \%$ cat. loading ( $0.53 \mathrm{~mol} \%$ relative to ester linkages). N.B. $Y_{\text {Me-LA }}$ refers to maximum Me-LA conversion determined via ${ }^{1} \mathrm{H}$ NMR $\left(\mathrm{CDCl}_{3}\right)$ after $8 \mathrm{~h}$ prior to solvent (THF) removal.

entries 12 and 16) following solvent removal revealed the formation of a new $\mathrm{Mg}$ (II)-species, although its identity remains unclear. It is suggested the dimeric framework dissociates in solution, affording a heteroleptic complex of the general formula $\mathrm{Mg}(\mathbf{1}, 3) \mathrm{L}$, where $\mathrm{L}$ could be methoxy, lactyl or higher chain oligomers, as previously described by Jones and coworkers. $^{123}$ Consequently, $[\mathrm{Mg}(\mathbf{1}, 3)]_{2}$ should strictly be regarded as pre-catalysts and this can likely be extended to the remaining $\mathrm{Zn}$ (II)-complexes.

PET degradation. Presently, bio-based plastics account for ca. $1 \%$ of all processed plastics, with PLA accounting for just $13.9 \%$ of bioplastic production in $2019 .{ }^{126}$ Consequently, our attention shifted to PET, a commercial polyester widely exploited in the packaging industry, which consumed $38 \%$ of plastics produced globally in 2015, with PET accounting for $22.6 \%$ of plastic use in the sector. ${ }^{13}$ Glycolysis is the most widely used chemical recycling method for PET, characterised by cleavage of the ester bond via insertion of a glycol, commonly ethylene glycol (EG), to produce bis(2-hydroxyethyl) terephthalate (BHET) or higher alcohol derivatives. BHET can then be repolymerised to virgin PET or used as a precursor in the production of unsaturated polyester resins. ${ }^{127-131}$ In light of this, preliminary work sought to apply $[\mathrm{Zn}(\mathbf{1}, \mathbf{3})]_{2}$ and $[\mathrm{Mg}(\mathbf{1})]_{2}$ to the glycolysis of PET. $[\mathrm{Mg}(3)]_{2}$ was not investigated due to insufficient yield. Typically, high temperatures $\left(180-240{ }^{\circ} \mathrm{C}\right)$ and prolonged reaction times $(0.5-8 \mathrm{~h})$ in the presence of a transesterification catalyst, often a metal acetate, are required to achieve appreciable conversion. Whilst numerous metal acetate catalysts have been reported in the literature, zinc acetate is considered the benchmark. ${ }^{127,132}$

Consequently, $\mathrm{Zn}(\mathrm{OAc})_{2} \cdot 2 \mathrm{H}_{2} \mathrm{O}$ (Sigma Aldrich) was chosen as an air-stable, commercially available reference. Additionally, high EG: PET $(\geq 5: 1)$ are used to mediate the formation of higher chain oligomers, thus favouring the formation of BHET. ${ }^{127}$ As such, a reaction temperature of $180{ }^{\circ} \mathrm{C}$ in the presence of 8 wt $\%$ catalyst and 27.5 equivalents of EG was chosen (Table 5). Two sources of PET were selected: 1 . A carbonated drinks bottle $\left(M_{\mathrm{n}} \sim 40000 \mathrm{~g} \mathrm{~mol}{ }^{-1}\right)$ and 2 . Thin-films, representing waste from the manufacturing industry (Fig. 7).

Typically, a 6-12\% reduction in $Y_{\text {BHET (isolated yield) was }}$ observed on accounting for residual $\mathrm{H}_{2} \mathrm{O}$ (1.3-3.5 equivalents) 
Table 5 PET degradation into BHET using selected $\mathrm{Zn}(\Perp)$ - and $\mathrm{Mg}(\Perp)$-catalen complexes at $180^{\circ} \mathrm{C}$

\begin{tabular}{|c|c|c|c|c|c|c|c|}
\hline Catalyst & Time/h & $T /{ }^{\circ} \mathrm{C}$ & Cat. loading/wt $\%$ & EG/equiv. & $Y_{\text {BHET }}($ wet $)(g / \%)$ & $\mathrm{H}_{2} \mathrm{O} /$ equiv. & Corrected $Y_{\mathrm{BHET}}(\%)$ \\
\hline \multirow[t]{2}{*}{ Ref } & 4 & 180 & 8 & 27.5 & $0.16(48 \%)$ & 2.0 & 42 \\
\hline & $2^{a}$ & 180 & 8 & 27.5 & $0.14(42 \%)$ & 2.1 & 37 \\
\hline$[\mathrm{Zn}(1)]_{2}$ & 4 & 180 & 8 & 27.5 & $0.20(61 \%)$ & 3.3 & 49 \\
\hline$[\mathrm{Zn}(3)]_{2}$ & 4 & 180 & 8 & 27.5 & $0.16(48 \%)$ & 1.3 & 44 \\
\hline \multirow[t]{3}{*}[\mathrm{Mg}(1)]{$_{2}$} & 3 & 180 & 8 & 27.5 & $0.20(61 \%)$ & 2.7 & 51 \\
\hline & $0.75^{a}$ & 180 & 8 & 27.5 & $0.14(42 \%)$ & 3.5 & 34 \\
\hline & $3^{b}$ & 180 & 8 & 27.5 & $0.18(55 \%)$ & 2.4 & 46 \\
\hline
\end{tabular}

Reaction conditions: $0.25 \mathrm{~g}$ of carbonated drinks bottle $\left(M_{\mathrm{n}} \sim 40000 \mathrm{~g} \mathrm{~mol}{ }^{-1}\right), 27.5$ equivalents of EG (relative to ester linkages), Ref: $\mathrm{Zn}(\mathrm{OAc})_{2} \cdot 2 \mathrm{H}_{2} \mathrm{O}=8 \mathrm{wt} \%$ cat. loading $(0.02 \mathrm{~g}, 7 \mathrm{~mol} \%$ relative to ester linkages $)$, $[\mathrm{Zn}(1,3)]_{2}=8 \mathrm{wt} \%$ cat. loading $(0.02 \mathrm{~g}, 1.3-1.4 \mathrm{~mol} \% \mathrm{relative}$ to ester linkages), $[\mathrm{Mg}(\mathbf{1})]_{2}=8 \mathrm{wt} \%$ cat. loading $\left(0.02 \mathrm{~g}, 1.5 \mathrm{~mol} \%\right.$ relative to ester linkages). ${ }^{a}$ PET thin-film $(0.25 \mathrm{~g}) .{ }^{b}$ PET $(0.25 \mathrm{~g}$, carbonated drinks bottle) + PVC $\left(0.025 \mathrm{~g}, 10 \mathrm{wt} \%\right.$, Sigma Aldrich, $\left.M_{\mathrm{n}} \sim 22000 \mathrm{~g} \mathrm{~mol}{ }^{-1}\right)$. N.B. $Y_{\text {BHET }}$ (wet) refers to the isolated yield of BHET recrystallised from deionised $\mathrm{H}_{2} \mathrm{O}$, followed by drying at $90{ }^{\circ} \mathrm{C}$ for $3 \mathrm{~h}$ in vacuo. Residual $\mathrm{H}_{2} \mathrm{O}$ (equiv.) was determined via ${ }^{1} \mathrm{H}$ NMR ( $\mathrm{D}_{6}$-DMSO) analysis. A corrected $Y_{\mathrm{BHET}}$ is provided accounting for the complete removal of $\mathrm{H}_{2} \mathrm{O}$.
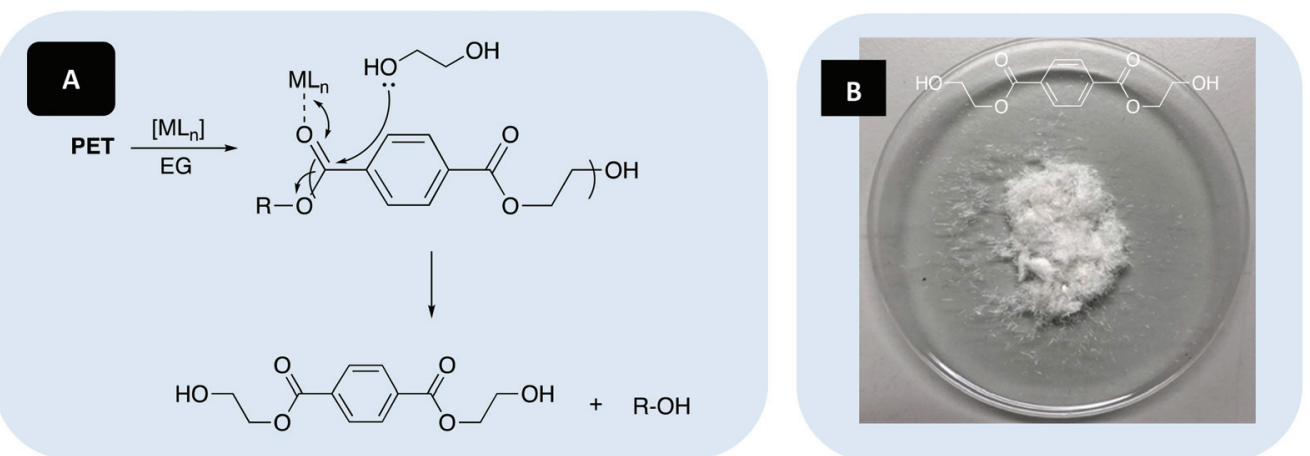

Fig. 7 (A) Metal mediated glycolysis of poly(ethylene terephthalate) (PET) into bis(2-hydroxyethyl) terephthalate (BHET) in the presence of ethylene glycol (EG), where R denotes the growth polymer chain. (B) Example of recycled product (BHET).

after drying, and thus cannot be considered absolute. Consequently, the discussion of $Y_{\text {ВНET }}$ herein will refer to the corrected value. $[\mathrm{Zn}(\mathbf{1}, \mathbf{3})]_{2}$ exhibited comparable performance to the reference, achieving between $44-49 \% Y_{\text {BHET }}$ within $4 \mathrm{~h}$ at $180{ }^{\circ} \mathrm{C}$. Promisingly, $[\mathrm{Mg}(\mathbf{1})]_{2}$ exhibited superior activity, ascertaining the highest $Y_{\text {BHET }}$ observed, achieving 51\% within $3 \mathrm{~h}$ under analogous conditions. For this system, tolerance stability was successfully demonstrated in the presence of $10 \mathrm{wt} \%$ PVC, retaining comparable $Y_{\text {BHET }}$ (46\%; Table 5, entry 7). PVC contamination as low as $100 \mathrm{ppm}$ has previously been reported to adversely impact the quality of the final recycled product, owing to the production of acid catalysts that facilitate chain scission under melt reprocessing conditions $\left(T=160{ }^{\circ} \mathrm{C}\right)$ routinely employed in industry. ${ }^{127}$ Thus, this result is particularly promising from an industrial perspective. Both $[\mathrm{Mg}(\mathbf{1})]_{2}$ and $\mathrm{Zn}(\mathrm{OAc})_{2} \cdot 2 \mathrm{H}_{2} \mathrm{O}$ exhibited superior activity on substituting the carbonated drinks bottle for thin-films, owing to superior sample dissolution. Remarkably, $[\mathrm{Mg}(\mathbf{1})]_{2}$ achieved 34\% $Y_{\text {BHET }}$ within 45 minutes, vastly outperforming the reference, which afforded comparable conversion within $2 \mathrm{~h}\left(Y_{\text {BHET }}=37 \%\right.$; Table 5 , entry 2$)$. Whilst reaction times reflect the time taken to achieve complete PET dissolution, indicative of reaction completion, $Y_{\mathrm{BHET}}$ less than $50 \%$ were typically observed. It is possible the production of higher chain oligomers is partly responsible. ${ }^{127-132}$ In summary, [Zn $(\mathbf{1}, \mathbf{3})]_{2}$ and $[\mathrm{Mg}(\mathbf{1})]_{2}$ exhibited superior activity for PET glycolysis relative to $\mathrm{Zn}(\mathrm{OAc})_{2} \cdot 2 \mathrm{H}_{2} \mathrm{O}$, despite the $\mathrm{wt} \%$ of the reference corresponding to a significantly higher zinc loading, highlighting the importance of structure-activity relationships.

\section{Conclusions}

A range of dimeric $\mathrm{Zn}$ (II)- and $\mathrm{Mg}$ (II)-catalen complexes were prepared and fully characterised. The production of biocompatible atactic PLA in solution and under industrially preferred solvent-free conditions was demonstrated, typically observing good activity and $M_{\mathrm{n}}$ control with a broad range of dispersities $(\nexists=1.08-2.04) . \mathrm{Mg}(\mathrm{II})$-Complexes were shown to facilitate the relatively mild methanolysis of PLA, achieving up to $64 \%$ conversion to Me-LA within $8 \mathrm{~h}$ at $80^{\circ} \mathrm{C}$ in THF. Further kinetic analysis found $[\mathrm{Mg}(\mathbf{1}, \mathbf{3})]_{2}$ to have $k_{\text {app }}$ values of $0.628 \pm 0.0536$ $\{4$ wt $\%$ cat. loading $\}$ and $0.265 \pm 0.0193 \mathrm{~h}^{-1}\{8 \mathrm{wt} \%$ cat. loading $\}$ respectively. For $[\mathrm{Mg}(\mathbf{1})]_{2}$, increasing the catalyst loading to $8 \mathrm{wt} \%$ resulted in a statistically significant reduction in activity $\left(0.0819 \pm 0.0213 \mathrm{~h}^{-1}\right)$, potentially evidencing catalyst aggregation, which appeared prevalent in the 
Zn(II)-complexes. Preliminary work extended polymer scope to PET from various sources, demonstrating catalyst versatility.

\section{Conflicts of interest}

The authors declare no conflict of interest.

\section{Acknowledgements}

We wish to thank the EPSRC for funding and the University of Bath and $\mathrm{MC}^{2}$ for use of their analysis facilities. We would like to thank the EPSRC for funding (EP/L016354/1) for a PhD studentship to J. P. and (EP/P016405/1) for P. M. We thank Avery Dennison for kindly providing waste PET thin-films used in this study.

\section{References}

1 R. A. Sheldon and M. Norton, Green Chem., 2020, 22, 6310-6322.

2 PlasticsEurope, Plastics - the Facts 2019. An Analysis of European Plastics Production, Demand and Waste Data, 2019, https:/www.plasticseurope.org/application/files/9715/7129/ 9584/FINAL_web_version_Plastics_the_facts2019_14102019. pdf, (Accessed: 13th October 2020).

3 J. Payne, P. McKeown and M. D. Jones, Polym. Degrad. Stab., 2019, 165, 170-181.

4 R. Geyer, J. R. Jambeck and K. L. Law, Sci. Adv., 2017, 3, 15.

5 R. C. Thompson, C. J. Moore, F. S. vom Saal and S. H. Swan, Philos. Trans. R. Soc., B, 2009, 364, 2153-2166.

6 Y. Zhu, C. Romain and C. K. Williams, Nature, 2016, 540, 354-362.

7 Ellen MacArthur Foundation, The New Plastics Economy: Rethinking the future of plastics, 2016, https://www.ellenmacarthurfoundation.org/publications/the-new-plastics-economyrethinking-the-future-of-plastics, (Accessed: 7th January 2019).

8 J. R. Jambeck, R. Geyer, C. Wilcox, T. R. Siegler, M. Perryman, A. Andrady and R. Na, Science, 2015, 347, 768-771.

9 L. Lebreton, B. Slat, F. Ferrari, B. Sainte-Rose, J. Aitken, R. Marthouse, S. Hajbane, S. Cunsolo, A. Schwarz, A. Levivier, K. Noble, P. Debeljak, H. Maral, R. Schoeneich-Argent, R. Brambini and J. Reisser, Sci. Rep., 2018, 8, 4666.

10 E. T. H. Vink, K. R. Rábago, D. A. Glassner, B. Springs, R. P. O'Connor, J. Kolstad and P. R. Gruber, Macromol. Biosci., 2004, 4, 551-564.

11 E. T. H. Vink, D. A. Glassner, J. Kolstad, R. J. Wooley and R. P. O'Connor, Biotechnology, 2007, 3, 58-81.

12 J. Lunt, Polym. Degrad. Stab., 1998, 59, 145-152.

13 M. Rabnawaz, I. Wyman, R. Auras and S. Cheng, Green Chem., 2017, 19, 4737-4753.
14 R. E. Drumright, P. R. Gruber and D. E. Henton, $A d v$. Mater., 2000, 12, 1841-1846.

15 O. Dechy-Cabaret, B. Martin-Vaca and D. Bourissou, Chem. Rev., 2004, 104, 6147-6176.

16 R. H. Platel, L. M. Hodgson and C. K. Williams, Polym. Rev., 2008, 48, 11-63.

17 H. R. Kricheldorf, I. Kreiser-Saunders and A. Stricker, Macromolecules, 2000, 33, 702-709.

18 N. Spassky, M. Wisniewski, C. Pluta and A. LeBorgne, Macromol. Chem. Phys., 1996, 197, 2627-2637.

19 Z. Y. Zhong, P. J. Dijkstra and J. Feijen, Angew. Chem., Int. Ed., 2002, 41, 4510-4513.

20 Z. Zhong, P. J. Dijkstra and J. Feijen, J. Am. Chem. Soc., 2003, 125, 11291-11298.

21 N. Nomura, R. Ishii, M. Akakura and K. Aoi, J. Am. Chem. Soc., 2002, 124, 5938-5939.

22 N. Nomura, R. Ishii, Y. Yamamoto and T. Kondo, Chem. Eur. J., 2007, 13, 4433-4451.

23 H.-L. Chen, S. Dutta, P.-Y. Huang and C.-C. Lin, Organometallics, 2012, 31, 2016-2025.

24 E. L. Whitelaw, G. Loraine, M. F. Mahon and M. D. Jones, Dalton Trans., 2011, 40, 11469-11473.

25 A. Pilone, K. Press, I. Goldberg, M. Kol, M. Mazzeo and M. Lamberti, J. Am. Chem. Soc., 2014, 136, 2940-2943.

26 P. McKeown, M. G. Davidson, G. Kociok-Köhn and M. D. Jones, Chem. Commun., 2016, 52, 10431-10434.

27 P. Hormnirun, E. L. Marshall, V. C. Gibson, A. J. P. White and D. J. Williams, J. Am. Chem. Soc., 2004, 126, 2688-2689.

28 P. Hormnirun, E. L. Marshall, V. C. Gibson, R. I. Pugh and A. J. P. White, Proc. Natl. Acad. Sci. U. S. A., 2006, 103, 15343-15348.

29 H. Du, A. H. Velders, P. J. Dijkstra, J. Sun, Z. Zhong, X. Chen and J. Feijen, Chem. - Eur. J., 2009, 15, 98369845.

30 J. Feijen, Chem. - Eur. J., 2009, 15, 9836-9845.

31 K. Press, I. Goldberg and M. Kol, Angew. Chem., Int. Ed., 2015, 54, 14858-14861.

32 R. Hador, A. Botta, V. Venditto, S. Lipstman, I. Goldberg and M. Kol, Angew. Chem., Int. Ed., 2019, 58, 14679-14685.

33 S. Gesslbauer, H. Cheek, A. J. P. White and C. Romain, Dalton Trans., 2018, 47, 10410-10414.

34 S. Gesslbauer, R. Savela, Y. Chen, A. J. P. White and C. Romain, ACS Catal., 2019, 9, 7912-7920.

35 J. Payne, P. McKeown, G. Kociok-Köhn and M. D. Jones, Chem. Commun., 2020, 56, 7163-7166.

36 A. J. Chmura, M. G. Davidson, M. D. Jones, M. D. Lunn, M. F. Mahon, A. F. Johnson, P. Khunkamchoo, S. L. Roberts and S. S. F. Wong, Macromolecules, 2006, 39, 7250-7257.

37 A. J. Chmura, M. G. Davidson, C. J. Frankis, M. D. Jones and M. D. Lunn, Chem. Commun., 2008, 1293-1295.

38 A. J. Chmura, M. G. Davidson, C. J. Frankis, M. D. Jones and M. D. Lunn, Chem. Commun., 2008, 1293-1295.

39 A. Sauer, A. Kapelski, C. Fliedel, S. Dagorne, M. Kol and J. Okuda, Dalton Trans., 2013, 42, 9007-9023.

40 E. Sergeeva, J. Kopilov, I. Goldberg and M. Kol, Inorg. Chem., 2010, 49, 3977-3979. 
41 S. Gendler, S. Segal, I. Goldberg, Z. Goldschmidt and M. Kol, Inorg. Chem., 2006, 45, 4783-4790.

42 A. Stopper, J. Okuda and M. Kol, Macromolecules, 2012, 45, 698-704.

43 J.-C. Buffet and J. Okuda, Polym. Chem., 2011, 2, 27582763.

44 C. Romain, B. Heinrich, S. B. Laponnaz and S. Dagorne, Chem. Commun., 2012, 48, 2213-2215.

45 X. Wang, A. Thevenon, J. L. Brosmer, I. Yu, S. I. Khan, P. Mehrkhodavandi and P. L. Diaconescu, J. Am. Chem. Soc., 2014, 136, 11264-11267.

46 M. D. Jones, S. L. Hancock, P. McKeown, P. M. Schafer, A. Buchard, L. H. Thomas, M. F. Mahon and J. P. Lowe, Chem. Commun., 2014, 50, 15967-15970.

47 M. D. Jones, L. Brady, P. McKeown, A. Buchard, P. M. Schafer, L. H. Thomas, M. F. Mahon, T. J. Woodman and J. P. Lowe, Chem. Sci., 2015, 6, 5034-5039.

48 E. L. Whitelaw, M. F. Mahon and M. D. Jones, Inorg. Chem., 2010, 49, 7176-7181.

49 E. L. Whitelaw, M. G. Davidson and M. D. Jones, Chem. Commun., 2011, 47, 10004-10006.

50 B. M. Chamberlain, M. Cheng, D. R. Moore, T. M. Ovitt, E. B. Lobkovsky and G. W. Coates, J. Am. Chem. Soc., 2001, 123, 3229-3238.

51 M. H. Chisholm, J. C. Gallucci and K. Phomphrai, Inorg. Chem., 2005, 44, 8004-8010.

52 H.-Y. Chen, H.-Y. Tang and C.-C. Lin, Macromolecules, 2006, 39, 3745-3752.

53 J. Borner, U. Florke, K. Huber, A. Doring, D. Kuckling and S. Herres-Pawlis, Chem. - Eur. J., 2009, 15, 2362-2376.

54 D. J. Darensbourg and O. Karroonnirun, Inorg. Chem., 2010, 49, 2360-2371.

55 J. Börner, I. dos Santos Vieira, A. Pawlis, A. Döring, D. Kuckling and S. Herres-Pawlis, Chem. - Eur. J., 2011, 17, 4507-4512.

56 H. Wang and H. Ma, Chem. Commun., 2013, 49, 86868688.

57 C. Fliedel, D. Vila-Viçosa, M. J. Calhorda, S. Dagorne and T. Avilés, ChemCatChem, 2014, 6, 1357-1367.

58 H. Wang, Y. Yang and H. Ma, Macromolecules, 2014, 47, 7750-7764.

59 Y. Yang, H. Wang and H. Ma, Inorg. Chem., 2015, 54, 5839-5854.

60 T. Rosen, Y. Popowski, I. Goldberg and M. Kol, Chem. Eur. J., 2016, 22, 11533-11536.

61 P. M. Schäfer, M. Fuchs, A. Ohligschläger, R. Rittinghaus, P. McKeown, E. Akin, M. Schmidt, A. Hoffmann, M. A. Liauw, M. D. Jones and S. Herres-Pawlis, ChemSusChem, 2017, 10, 3547-3556.

62 D. E. Stasiw, A. M. Luke, T. Rosen, A. B. League, M. Mandal, B. D. Neisen, C. J. Cramer, M. Kol and W. B. Tolman, Inorg. Chem., 2017, 56, 14366-14372.

63 S. Abbina and G. Du, ACS Macro Lett., 2014, 3, 689-692.

64 C. K. Williams, L. E. Breyfogle, S. K. Choi, W. Nam, V. G. Young, M. A. Hillmyer and W. B. Tolman, J. Am. Chem. Soc., 2003, 125, 11350-11359.
65 M. Cheng, A. B. Attygalle, E. B. Lobkovsky and G. W. Coates, J. Am. Chem. Soc., 1999, 121, 11583-11584.

66 A. Thevenon, C. Romain, M. S. Bennington, A. J. P. White, H. J. Davidson, S. Brooker and C. K. Williams, Angew. Chem., Int. Ed., 2016, 55, 8680-8685.

67 C. Kan, J. Hu, Y. Huang, H. Wang and H. Ma, Macromolecules, 2017, 50, 7911-7919.

68 P. McKeown, S. N. McCormick, M. F. Mahon and M. D. Jones, Polym. Chem., 2018, 9, 5339-5347.

69 Al. Hermann, S. Hill, A. Metz, J. Heck, A. Hoffmann, L. Hartmann and S. Herres-Pawlis, Angew. Chem., Int. Ed., 2020, 59(48), 21778-21784.

70 J. Kasperczyk and M. Bero, Polymer, 2000, 41, 391-395.

71 L. F. Sánchez-Barba, A. Garcés, M. Fajardo, C. AlonsoMoreno, J. Fernández-Baeza, A. Otero, A. Antiñolo, J. Tejeda, A. Lara-Sánchez and M. I. López-Solera, Organometallics, 2007, 26, 6403-6411.

72 V. Poirier, T. Roisnel, J.-F. Carpentier and Y. Sarazin, Dalton Trans., 2009, 9820-9827.

73 C. A. Wheaton, P. G. Hayes and B. J. Ireland, Dalton Trans., 2009, 4832-4846.

74 L. Wang and H. Ma, Macromolecules, 2010, 43, 6535-6537.

75 L. F. Sánchez-Barba, A. Garcés, J. Fernández-Baeza, A. Otero, C. Alonso-Moreno, A. Lara-Sánchez and A. M. Rodríguez, Organometallics, 2011, 30, 2775-2789.

76 H.-J. Chuang, H.-L. Chen, J.-L. Ye, Z.-Y. Chen, P.-L. Huang, T.-T. Liao, T.-E. Tsai and C.-C. Lin, J. Polym. Sci., Part A: Polym. Chem., 2013, 51, 696-707.

77 A. Garcés, L. F. Sánchez-Barba, J. Fernández-Baeza, A. Otero, M. Honrado, A. Lara-Sánchez and A. M. Rodríguez, Inorg. Chem., 2013, 52, 12691-12701.

78 W. Yi and H. Ma, Inorg. Chem., 2013, 52, 11821-11835.

79 M. J. Walton, S. J. Lancaster and C. Redshaw, ChemCatChem, 2014, 6, 1892-1898.

80 K. Devaine-Pressing, J. H. Lehr, M. E. Pratt, L. N. Dawe, A. A. Sarjeant and C. M. Kozak, Dalton Trans., 2015, 44, 12365-12375.

81 H. Wang, J. Guo, Y. Yang and H. Ma, Dalton Trans., 2016, 45, 10942-10953.

82 P. McKeown, J. Brown-Humes, M. G. Davidson, M. F. Mahon, T. J. Woodman and M. D. Jones, Dalton Trans., 2017, 46, 5048-5057.

83 M. H. Chisholm, K. Choojun, A. S. Chow, G. Fraenkel and J. C. Gallucci, Inorg. Chem., 2013, 52, 11302-11310.

84 M. H. Chisholm, K. Choojun, J. C. Gallucci and P. M. Wambua, Chem. Sci., 2012, 3, 3445-3457.

85 M. H. Chisholm, J. Gallucci and K. Phomphrai, Inorg. Chem., 2002, 41, 2785-2794.

86 T. P. Haider, C. Völker, J. Kramm, K. Landfester and F. R. Wurm, Angew. Chem., Int. Ed., 2019, 58, 50-62.

87 J. Hopewell, R. Dvorak and E. Kosior, Philos. Trans. R. Soc., $B, 2009,364,2115-2126$.

88 M. Hong and E. X.-Y. Chen, Green Chem., 2017, 9, 36923706.

89 P. McKeown and M. D. Jones, Sustainable Chem., 2020, 1, 1-22. 
90 C. T. Bowmer, R. N. Hooftman, A. O. Hanstveit, P. W. M. Venderbosch and N. van der Hoeven, Chemosphere, 1998, 37, 1317-1333.

91 C. S. M. Pereira, V. M. T. M. Silva and A. E. Rodrigues, Green Chem., 2011, 13, 2658-2671.

92 M. Dusselier, P. V. Wouwe, A. Dewaele, E. Makshina and B. F. Sels, Energy Environ. Sci., 2013, 6, 1415-1442.

93 Y. Fan, C. Zhou and X. Zhu, Catal. Rev. Sci. Eng., 2009, 51, 293-324.

94 V. Piemonte, S. Sabatini and F. Gironi, J. Polym. Environ., 2013, 21, 640-647.

95 F. M. Lamberti, L. A. Román-Ramírez, P. Mckeown, M. D. Jones and J. Wood, Processes, 2020, 8, 738.

96 H. Tsuji, T. Saeki, T. Tsukegi, H. Daimon and K. Fujie, Polym. Degrad. Stab., 2008, 93, 1956-1963.

97 V. Piemonte and F. Gironi, J. Polym. Environ., 2013, 21, 313-318.

98 P. Coszach, J.-C. Bogaert and J. Willocq, US Pat, 8431683B2, 2013.

99 C. F. VanNostrum, T. F. J. Veldhuis, G. W. Bos and W. E. Hennink, Polymer, 2004, 45, 6779-6787.

100 H. Tsuji, H. Daimon and K. Fujie, Biomacromolecules, 2003, 4, 835-840.

101 F. Codari, S. Lazzari, M. Soos, G. Storti, M. Morbidelli and D. Moscatelli, Polym. Degrad. Stab., 2012, 97, 2460-2466.

102 K. Odelius, A. Höglund, S. Kumar, M. Hakkarainen, A. K. Ghosh, N. Bhatnagar and A. C. Albertsson, Biomacromolecules, 2011, 12, 1250-1258.

103 K. Hirao, Y. Nakatsuchi and H. Ohara, Polym. Degrad. Stab., 2010, 95, 925-928.

104 L. D. Brake, US Pat, 5264617, 1993.

105 X. Song, X. Zhang, H. Wang, F. Liu, S. Yu and S. Liu, Polym. Degrad. Stab., 2013, 98, 2760-2764.

106 X. Song, H. Wang, X. Zheng, F. Liu and S. Yu, J. Appl. Polym. Sci., 2014, 131, 40817-40822.

107 C. Fliedel, D. Vila-Viçosa, M. J. Calhorda, S. Dagorne and T. Avilés, ChemCatChem, 2014, 6, 1357-1367.

108 E. L. Whitelaw, M. G. Davidson and M. D. Jones, Chem. Commun., 2011, 47, 10004-10006.

109 L. A. Román-Ramírez, P. Mckeown, M. D. Jones and J. Wood, ACS Catal., 2019, 9, 409-416.

110 J. Payne, P. McKeown, M. F. Mahon, E. A. C. Emanuelsson and M. D. Jones, Polym. Chem., 2020, 11, 2381-2389.

111 R. Petrus, D. Bykowski and P. Sobota, ACS Catal., 2016, 6, 5222-5235.

112 F. A. Leibfarth, N. Moreno, A. P. Hawker and J. D. Shand, J. Polym. Sci., Part A: Polym. Chem., 2012, 50, 4814-4822.

113 F. Nederberg, E. F. Connor, T. Glausser and J. L. Hedrick, Chem. Commun., 2001, 2066-2067.
114 P. McKeown, M. Kamran, M. G. Davidson, M. D. Jones, L. A. Román-Ramírez and J. Wood, Green Chem., 2020, 22, 3721-3726.

115 A. C. Sanchéz and R. S. Collinson, Eur. Polym. J., 2011, 47, 1970-1976.

116 S. Westhues, J. Idel and J. Klankermayer, Sci. Adv., 2018, 1-9.

117 E. M. Krall, T. W. Klein, R. J. Andersen, A. J. Nett, R. W. Glasgow, D. S. Reader, B. C. Dauphinais, S. P. Mc Ilrath, A. A. Fischer, M. J. Carney, D. J. Hudson and N. J. Robertson, Chem. Commun., 2014, 50, 4884-4887.

118 T.-O. Kindler, C. Alberti, E. Fedorenko, N. Santangelo and S. Enthaler, ChemistryOpen, 2020, 9, 401-404.

119 L. Monsigny, J.-C. Berthet and T. Cantat, ACS Sustainable Chem. Eng., 2018, 6, 10481-10488.

120 H. Liu, X. Song, F. Liu, S. Liu and S. Yu, J. Polym. Res., 2015, 22, 135-141.

121 C. Alberti, N. Damps, R. R. R. Meißner, M. Hofmann, D. Rijono and S. Enthaler, Adv. Sustainable Syst., 2020, 4, 1900081.

122 M. Hofmann, C. Alberti, F. Scheliga, R. R. R. Meißner and S. Enthaler, Polym. Chem., 2020, 11, 26252629.

123 P. McKeown, L. A. Román-Ramírez, S. Bates, J. Wood and M. D. Jones, ChemSusChem, 2019, 12, 52335238.

124 A. J. Hunt, T. J. Farmer and J. H. Clark, Chapter 1 Elemental Sustainability and the Importance of Scarce Element Recovery, in Element Recovery and Sustainability, ed. A. Hunt, RSC, 2013, ch. 1, pp. 1-28.

125 ACS, 12 Principles of Green Chemistry, https://www.acs.org/ content/acs/en/greenchemistry/principles/12-principles-ofgreen-chemistry.html, (Accessed: 19th October 2020).

126 European Bioplastics, Facts and Figures, https://docs.european-bioplastics.org/publications/EUBP_Facts_and_figures. pdf, (Accessed: 20th October 2020).

127 F. M. Lamberti, L. A. Román-Ramírez and J. Wood, J. Polym. Environ., 2020, 28, 2551-2571.

128 V. Sinha, M. R. Patel and J. V. Patel, J. Polym. Environ., 2010, 18, 8-25.

129 S. M. Al-Salem, P. Lettieri and J. Baeyens, Waste Manage., 2009, 29, 2625-2643.

130 G. P. Karayannidis and D. S. Achilias, Macromol. Mater. Eng., 2007, 292, 128-146.

131 D. Paszun and T. Spychaj, Ind. Eng. Chem. Res., 1997, 36, 1373-1383.

132 K. R. Della Chiaie, F. R. McMahon, E. J. Williams, M. J. Price and A. P. Dove, Polym. Chem., 2020, 11, 14501453. 